Web jurnal online: jurnal.unmuhjember.ac.id

By: Dewinta Rizky R.Hatu, DarsonoWisadhirana, Edi Susilo

The Role of Local Wisdom as Social Capital of Remote Indigenous Communities RIC)

\title{
The Role of Local Wisdom as Social Capital of Remote Indigenous Communities (RIC)
}

\author{
by:Dewinta Rizky R. Hatu, DarsonoWisadhirana, Edi Susilo \\ *Univercity of Brawijaya \\ Email: dewintaarizky@gmail.com, \\ darsono_wisa@ub.ac.id, \\ olisuside@gmail.com
}

Received: 6 February2019, Revised: 13 February2019, Accepted: 28 February 2019

\begin{abstract}
This research sees that every community has local wisdom which is a source of social capital that can be accessed and utilized by its members. In this case, the community by itself builds their own social capital, with relationships built between communities through the local wisdom. The traditional remote community, certainly not separated from potential conflicts, but they can always overcome the potential conflicts that exist between them, because the role of local wisdom as a strong social capital among them. The theory used on this research is social capital Putnam and conducted in Buhu Village, Tibawa District, Gorontalo County, Indonesia. This research utilized case study as qualitative approach. Data collecting used in-depth interview, observation and documentation. Data were collected from six informants by using snowball sampling technique. This research found that the element of solidarity is important in building a strong social capital in the traditional remove community. This is different from Putnam which only emphasizes three elements, beliefs, networks and norms. In addition, the researchers found that in the process of networking, the traditional remote community is not only dealing with people they know, they are also different with Putnam as to realize various things, often people ask for help from their friends, family or trusted acquaintance (Field, 2010, hal. 3). The 'huyula' local wisdom that builds the social capital in the traditional remote community is able to bridge the differences that exist in a community, and can overcome the potential conflicts in the traditional remote community.
\end{abstract}

Keywords: 'huyula' local wisdom, social capital, traditional remote community. 


\section{INTRODUCTION}

Indonesia is a country with a diverse population consisting of various ethnic groups. Among the tribes and nations there are tribes that have experienced progress both in the social, political, economic and so on. Onthe other hand, there are also tribes who have not experienced progress and difficulties in access. Wiranto et al. (2014) said that the diversity and plurality of the tribes living in the interior had enriched the culture of the Indonesian nation and was an extraordinary potential for national security. Further, if this ethnic and cultural diversity are not managed wisely, it will be the seed of division between the tribes.

The existence of certain tribes or communities that are relatively left behind, isolated and remote is known as the Remote Indigenous Community. This term is a response to the criticism of the use of the term "alienated" community. The characteristics of the community in general, especially the people included in the "Remote Indigenous Communities" have similar characteristics and characteristics, among others: first, they live and grow in areas that are difficult to reach (remote, scattered, and mobile),second, the level of life/economic welfare is still very low; and third, lagging behind various aspects of life and the progress of society today that have been in touch with developments in a region.

The Directorate of Remote Indigenous Community Empowerment (2013) said that the population of Remote Indigenous Communities in Indonesia is still very large, amounting to 213,080 households. Of these numbers the population that has been empowered amounts to 88,512 households (41.54\%), who are being empowered totaling 5,871 households $(2.76 \%)$, while those who have not been empowered at all amount to 118,697 households (55.70\%).

Based on data from the Gorontalo Province Social Service in 2012, the total population of remote indigenous communities was 2,505 households (KK) spread across Boalemo District, Pohuwato, Gorontalo District, North Gorontalo District and Bone Bolango District. In the location of the study itself in Buhu Village, 
according to the data from the Gorontalo Provincial Social Service, there were 58 households (Grorontalo Provincial Social Service, 2014).

In the lives of the Remote Indigenous Communities, they tend to depend on the natural environment, only with a good natural environment KAT residents can survive. The Hated Indigenous Community of Durian Village, Buhu Village, is still alive and dependent on agricultural land. As a rural community, of course, with all the local wisdom, they always take advantage of their potential from farming, gardening and raising livestock. In this case, the Remote Indigenous Community (RIC) as a large part is engaged in the agricultural sector. In 2015, the largest number of livelihoods in the community of Buhu Village was engaged in the agricultural sector, which amounted to 408 people.

In general, the land ownership and control system for rural communities, especially those that are the location of the Remote Indigenous Community (RIC) in Durian Village, Buhu Village, is still traditional. Land in the village is owned by community members for generations with no clear legal status and ownership certification. Generally the land they live in and manage is owned by the state, as revealed by the Village Head who is the location of the Remote Indigenous Community (RIC), that "this area, because it is still APL, still state land, not yet given free land title" Although control of residential and agricultural land which is hereditary and without being based on legal force and certification of land tenure, does not result in ongoing conflict between one family and another family, even though the boundary of land between community groups and other communities is only proven by trees.

Every community has local wisdom as a source and social capital that can be accessed and utilized by its members. The Gorontalo community has the value of a mutual cooperation culture known as the 
"huyula" culture. Abdussammadin(Hatu, 2005) writes that Huyula as a form of help in society and bound to one another based on social relations called primordial bonds namely family ties and geographical location and faith, area, ethnicity and nation. This is certainly still very much held by the Remote Indigenous Community (RIC) community in Dusun Durian.

The local wisdom of the community or community is a potential social capital, where the community or community gives awareness and boundaries to the community, including contributing to meeting the needs and common interests (Abdullah, 2013, p. 1). In this case the community itself will build its own social capital, with the relationships that are built in the community through its local wisdom to foster good social capital.

From the explanation above, the researcher is interested in seeing the role of local wisdom as social capital in the Remote Indigenous Community (RIC) community. Then, how can the social capital formed in the lives of these remote indigenous communities help the community to avoid conflicts regarding traditional land tenure. Basically when land tenure is only traditional or has no legal status, in this case it does not have a certificate, it is prone to conflicts when land acquisition occurs both between communities and families. Especially in the Remote Indigenous Communities in Durian Hamlet, Buhu Village, it is still "ungala'a", which is usually the batih family who are still bound by relatives or who are still extended families. Land that is used and given downwardlyhasno provision on to whom the land is actually inherited, there is a tendency to feel the same ownership or the right to manage the land. Of course, when processing land, for example, there is a difference in opinion that there is the potential for conflict because both claims the same right of managing the land.

As in Rifa'I(2016, p. 86) who studied land tenure conflicts in the Kajujila Hamlet community, Sanalaok Village explained that land tenure conflicts occurred in the Kajujila Hamlet community due to several things, 
such as limited community land, no firmness in inheriting, and because there is no land certificate. This certainly shows that traditional land tenure tends to be prone to conflicts.

In fact, in the community of Remote Indigenous Communities (RIC) in Buhu Village, these conflicts can be avoided or do not cause a prolonged conflict. This certainly shows there is an interesting gap to study. Therefore, the researcher is interested in seeing the role of local wisdom as social capital in the Remote Indigenous Community (RIC) community in Durian Village, Buhu Village in avoiding conflicts over land tenure. The assumption is that there is the ability of the community to cooperate with each other which is inseparable from the role of local wisdom as the social capital they have. The nature of social capital is a social relationship that is interwoven in the daily lives of the citizens of the community by building a relationship with each other, and maintaining it so that it continues to be established, the same goal will be achieved. This paper explains how then the role of local wisdom as social capital in the prevention of land tenure conflicts in the community of Remote Indigenous Communities (RIC) in Durian Hamlet, Buhu Village, Gorontalo.

Efforts to create harmonization in people's lives will be far more efficient and effective if preventive measures are designed or carried out compared to repressive approaches. The preventive approach certainly minimizes the potential for conflict that exists in the dynamics of the development of people's lives in this study, which is expected to contribute to a harmonious model of life management in the community of Remote Indigenous Communities, which can later be a model approach to empowerment and development in remote indigenous communities .

\section{LITERATURE REVIEW}


This paper uses Putnam's social capital theory as an analysis technique. There are three components of Putnam's social capital, namely beliefs, norms and networks. Putnam's theory of social capital, which focuses on networks, norms and beliefs, is one of the elements in society. The collaborative process of social capital becomes energy and community strength, so it is considered relevant to see the prevention of conflict or problems in remote indigenous communities that are the focus of this research.

The community is essentially able to live in harmony and cooperate because there is a sense of trust, a mutual agreement or norm and network. This is consistent with social capital as a part of the social life of networks, norms and beliefs that encourage participants to act more effectively to achieve common goals (Field, 2010, p. 51). Trust is a pattern of mutual support between the two groups for mutual benefit, norms are rules that are expected to be adhered to between the two groups so that cooperation can work in accordance with the established rules and networks play a role in building coordination in the Remote Indigenous Communities.

Another dimension related to social capital is the typology of social capital. Social capital can be in the form of bonding or bridging. Social capital in the form of bonding is social capital in the context of inward looking ideas, relations and attention. This form of social capital generally appears and is in a society that tends to be homogeneous. Unlike bonding, social capital in the form of bridging is inclusive and outward looking. This form of bridging capital is also called the modern form of a grouping, group, association or community. Bridging social capital leads to the search for answers together to solve problems faced by groups by utilizing networks owned by individuals in groups. Linking Social is a social relationship characterized by relationships in

This paper uses Putnam's social capital theory as an analysis knife. There are three components of Putnam's social capital, namely beliefs, norms and networks. Putnam's theory of social capital, which focuses on networks, norms and beliefs, is one of the elements in society. The collaborative process of social 
capital becomes energy and community strength, so it is considered relevant to see the prevention of conflict or problems in remote indigenous communities that are the focus of this research.

The community is essentially able to live in harmony and cooperate because there is a sense of trust, there is a mutual agreement or norm and network. This is consistent with social capital which is part of the social life of networks, norms and beliefs that encourage participants to act more effectively to achieve common goals (Field, 2010, p. 51). Trust is a pattern of mutual support between the two groups for mutual benefit, norms are rules that are expected to be adhered to between the two groups so that cooperation can work in accordance with established rules and networks play a role in building coordination in the Remote Indigenous Communities.

Another dimension related to social capital is the typology of social capital. Social capital can be in the form of bonding or bridging. Social capital in the form of bonding is social capital in the context of inward looking ideas, relations and attention. This form of social capital generally appears and is in a society that tends to be homogeneous. Unlike bonding, social capital in the form of bridging is inclusive and outward looking. This form of bridging capital is also called the modern form of a grouping, group, association or community. Bridging social capital leads to the search for answers together to solve problems faced by groups by utilizing networks owned by individuals in groups. Linking Social is a social relationship characterized by a relationship between several levels of social strength and social status in the community (Hasbullah, 2006).

\section{RESEARCH METHODS}

This study uses qualitative methods with a case study approach. The main data collection technique is in-depth interviews. In addition, researchers also used observation and documentation collection techniques. In-depth interviews were used to explore local wisdom by the Remote Indigenous Community (RIC) community to produce strong social capital among them. In-depth interviews were 
conducted with six informants selected through the snowball sampling informant selection technique. The researcher determined the key informant and the main informant was the Village Chief. Furthermore, from the Village Head the data would include what the general conditions are and will give names that can be used as informants in this study. Then, the data obtained was analyzed using pattern matching techniques. The study was conducted in Durian Hamlet, Buhu Village, Tibawa District, Gorontalo District, Gorontalo Province.

\section{DISCUSSION}

\section{"Huyula" Value for Remote Indigenous Communities}

Huyula as a form of Gorontalo local wisdom is a series of mutual cooperation and cooperation. It is a social collaboration that is selfless and has long been practiced by ancestors and is a form of a coordinated and voluntary economic system. The relationship of ungalaa or kinship is very influential in the huyula system. As a combination of families who have blood lineage known as ungala'a, it seems that the huyula tradition is when there is a family from the RIC community or when the ungalaa wants to carry out a celebration or marriage, and so on, then all members who know you will do activities will come and help. Usually such work is carried out with selfless nature.

The first is Ambu, which is a help for common interests such as making new roads in the village and so on that focus on community service. For the people of the Remote Indigenous Community (RIC) in the Durian Huyula Hamlet, the ambu is still being carried out. Ambu is manifested in the activity of helping in mutual matters. As a community of only 58 families that lives in a small and very close environment, RIC community feel it is important to look after their area of residence. In addition to community service, RIC also works together to build facilities for their homes. The community took the initiative to make a gazebo for the place where they gathered and worked together. 
The researcher saw that the huyula in ambu form basically still needed to be implemented. In people's lives, because through such a process will create relationships and social contact between individuals and other communities. The RIC community can jointly maintain their environment. In contrast to the community with the central community of Buhu Village in general, according to Hatu's research $(2005$, p. 84) the central community of Buhu village generally changes its energy with material or money in the implementation of huyula in ambu.Givingmoney is a substitute for activities in ambu is easier than he has to leave his job such as trading, driving, etc. In the RIC community, researchers see, in addition to the economic income pattern is not too developed, the value of material (money) is not yet the main measure in the implementation process, but solely to maintain their location.

Second, Hileya that is the form of huyulacarried out by the community if there is a family or neighbor who experiences disaster in the form of grief. Then,people come to the place of grief to comfort the grieving person, and bring food to stay a few days. They cook food so the grieving personand comfort his heart. This process of activity is carried out by all layers of Gorontalo society, especially the Remote Indigenous Community (RIC) community in Durian Village, Buhu Village, especially if the RIC community still has family ties and kinship. Huyula activities in the form of hileyais done without expecting anything in return, except solely to provide assistance to families or relatives who experience disasters such as grief and accidents.

The huyula process in the form of hileya in the RIC community has spontaneous aspects in it, where without having to coordinate, the community will spontaneously come to help and entertain. When the RIC community heard that a family was grieving, they spontaneously arrived before the funeral process was held to be able to help prepare everything for the grieving family. The hileya process does not stop at the funeral, but continues in the process of aruah and ta'ziah. They spontaneously come to help prepare aruah, usually prepare food or join in reading the Quran. In addition to helping and bringing food, usually the 
family will stay for a few days in the hope that the bereaved family can comfort their hearts.

The RIC community in Durian Hamlet seems to still carry out huyula in the form of hileya in their social life. One of the essencesofHileya is that it can comfort grieving families by staying a few days with them. This is certainly very rare in the lives of Gorontalo people, even in the center of Buhu Village itself. According to Hatu's research (Hatu, 2005, p. 90) the community in the center of Buhu Village has changed or shifted in line with various developments and advances in the dynamics of people's lives. The central community of Buhu Village is totally unwilling to stay for a few days for families who have experienced disasters Reasons for unwillingness due to time factors and leaving the family: assistance is then provided in the form of sugar, cakes, money, rice, cooking oil, chicken, and energy such as helping to build additional temporary houses in the form of bantayo used for activities related to activities. For the RIC community they are still willing to help and even stay a few dayswith the grieving families. The researchers see this certainly is inseparable from their family system which is still very close because they live in the same location.

Third, Tiayo, a form of huyula, occurs between a group of people to do one's work. Usually people who are helped only provide food and are obliged to do the same thing in exchange if those who have helped have something to be done.Forexample on the first day of making house foundation, cultivating farmland, and so on. For the RIC community itself, Huyula in the form of tiayo is widely used for agriculture. The RIC community sometimes uses it in the process of breeding and harvesting.

However, by the huyula community in its present form the implementation now takes into account the value of material or money. The Remote Indigenous Community (RIC) in Durian Hamlet seems to experience a slight shift in the meaning of huyula in the form of love. They still work together in the process of breeding and harvesting, but what they used to do in a helping way without considering the material, seems to shift. 
Huyula in the form of tiayo in the life of the community of the Remote Data Community of Durian Village, Buhu Village, continues, but some have shifted or changed their meaning. Previously this did not require material value (money), now it has shifted a little. Some people pay more attention to material values (money) in order to increase family income when compared with the way of cooperation through community members and other communities. In the RIC community, they still want to carry out the agricultural process both the nursery and harvesting process to be done jointly (tiayo) and provide material rewards or wages. From the field data, the researchers saw that farmers invited by other farmers did not want to pay back their exhaustion with energy but had been assessed with material, namely wages.

\section{Huyula Value Builds Social Capital in Remote Indigenous Communities}

Each community basically has the source and potential of social capital that can be accessed and utilized by its members. A community is a potential social capital, where the community gives awareness and boundaries to the community, including contributing to meeting the needs and common interests. In this study, seeing the power of help in local wisdom, known as huyula, is a source of strong social capital among the people of the Remote Indigenous Community (RIC) of Durian Village. Huyula is a social collaboration that is selfless and has long been practiced by ancestors and is a form of a coordinated and voluntary economic system.

The RIC community is aware that doing the huyula makes the relationship among them more tightly connected. They not only help work and benefit each other, but also develop intimacywith their willingness. Although indeed their kinship relationship is indeed close, of course it is necessary to continue to be maintained, one of which is by interacting through a collaborative process. Collaboration is a joint effort between individuals or groups to achieve one or a common goal.

A very close relationship between local wisdom as social capital among the RIC community can be seen from the community doing their activities with 
their huyula form by working together on something, helping each other, indirectly fostering good interaction between communities and certainly building strong social capital among them. This is in line with the theory of social capital that adheres to the importance of relationships, because with the relationship that exists, a person can work together to obtain or achieve a goal that he initially did not reach alone. Relationships that are interwoven need to have a sense of fit and have a compatibility with each other. If they are of various values, they are very likely to work together to obtain goals that might work together to achieve mutually beneficial goals. Moreover, sometimes the community cooperates or helps spontaneously and voluntarily.

Things that were spontaneously and voluntarily applied by the people of the Durian Remote Indigenous Community (RIC) in Durian Village certainly helped to build social capital amongthem. Putnam believes that voluntary associations have an important role in efforts to develop social capital. Volunteering can be an arena for interaction between the actors gathered in it. Volunteering also helps foster trust or trust among the community. The local wisdom of the community or community is a potential social capital, where the community or community gives awareness and boundaries to the community, including contributing to meeting the needs and common interests (Abdullah, 2013, p. 1). The relationship of cooperation and help in the KAT in Durian Village has caused very strong and long-lasting social capital. A group that has high social capital will open the possibility to solve problems more easily.

\section{Elements of Social Capital in Remote Indigenous Communities (RIC)}

A community is a potential for social capital. Social capital refers to aspects of social organizations, such as beliefs, norms, and social networks that can facilitate collective action. Relationships built between communities on the ground have been built because the community of Remote Indigenous Communities (RIC) in Durian Hamlet is a community that has the same life and fate, kinship relations are still close. Relations between communities in Remote Indigenous 
Communities (RIC) have been formed from their sense of family. When the relationship has been formed, the community certainly has to maintain the relationship, the RIC community maintains relations between them by often gathering to just have a chat.

When talking about social capital in the community, there are important things that we can see. The researcher relates to the statement from Usman (2018), namely how a group, community or community develops and maintains social capital as a collective asset. Therefore, indirectly when the people of the Remote Indigenous Community (RIC) often gather tochat,they have contested and developed social capital amongthem.

The first element is trust. Mutual trust arises from the self-awareness of every member in the community that in doing collaboration all of them want to get the best results. The thicker the trust in others, the stronger the cooperation between them. As previously explained, the land tenure system in Durian Hamlet's Remote Indigenous Communities is still traditional and hereditary, therefore there needs to be a trust that is maintained well among thesociety.

The KAT community seeks to build trust in their fellow citizens, because they also carry out various forms of cooperation in their local wisdom, and to collaborate certainly requires a basis for mutual trust. This is in line with Putnam's statement that trust is the basis of moral behavior where social capital is built. Trust will facilitate cooperation. According to Putnam, trust is a form of desire to take risks in social relations based on feelings of confidence that others will do something as expected and act in a pattern of actions that support or not harm individuals and groups (Putnam, 2000, p. 19). The RIC community is aware that in collaboration they need mutual trust. Cooperation depend on trust, the greater the communication that is established (both directly and indirectly) between communities, the more they trust each other and they will find it easier to cooperate.

From the field data, the researchers saw a guarantee of honesty, cooperation and help in helping the people of the Remote Indigenous Community (RIC) in Durian 
Hamlet. This can strengthen a sense of solidarity and cooperative nature in the community. In addition, with mutual trust between those who work together, the risk of potential future conflicts decreases.

The second element is network. Remote Indigenous Communities (RIC) in Durian Hamlet even though they live in a small scope and are still in strong kinship ties, they continue to coordinate. This coordination is certainly related to the network. The inter-human network according to Putnam is important in the community.

Basically in every life of the community there must be a prominent figure. Even the RIC community. They have prominent figures. As already explained, the RIC community is a small and homogeneous community. RIC generally live in small groups. Before being empowered, they lived geographically isolated and were relatively difficult to reach. RIC is generally located in the interior, forests, mountains, hills, sea, swamp, beach areas that are difficult to reach.

So when they now move and live in a new place they need someone who is elder and helps coordinate between them and strengthen the network between them.

In huyula wisdom certainly requires networks Humans can relate to each other through networks and the tendency between them to share common values with each other in the network. These networks can enable people to work together between neighbors or each other and get mutual benefit. For things that are spontaneous as in the form of huyula in the form of hileya there is certainly no need for coordination between communities, the community has come to help spontaneously. But when there are members of those who need their help fly information by mouth.

Basically the network formed in the community of Remote Indigenous Communities (RIC) has a role in building coordination between communities. Every person's network has a certain pattern in interacting, making choices with whom to interact and for certain reasons. The network was originally a system of communication channels to protect and develop interpersonal relationships. The 
desire to join other people is partly due to the existence of shared values. The network of community involvement is an important form of social capital.

The RIC community also seems to be in the process of networking or collaborating with other people outside the community. They established good relations with the village government and also established a networking process with middlemen for their agricultural processes. Remote Indigenous Communities (RIC) appears to have relations with the government or groups that are considered strong to help them. To realize things with other people, people prefer to connect with people they know and can produce results (Field, 2010, p. 3). In reality in the field, the RIC community in working together is not only dealing with people they know. The RIC community wants a role from the Buhu Village Government. The role of the government is considered to be able to help them to get things they need more easily such as pennting letters and facilities for them. In essence, they relate not only to people they know but also to people who can benefit togethe

The third element is the norm. Norm according to Putnam is a set of rules that are expected to be obeyed by members of the community on a particular social entity (Lawang, 2004, p. 70). These norms arise from mutually beneficial exchanges. That is, if profits are only enjoyed by one party, then the relationship will stop and no exchange will occur. Conversely, when exchanges are beneficial for both parties, the relationship will continue to be intertwined and exchange repetitions will occur, hoping to gain profits. Therefore, the researchers see that norms will emerge in the form of social obligations, which essentially makes both parties feel benefited through the exchange.

In the life of the people of the Remote Indigenous Community there are agreements between them which will certainly make the cooperation relationship continue and profitable for both parties who cooperate. An agreement to help alternately is certainly the norm that they agree on together. In addition, as previously explained, this is an obligation, when assisted, of course, it is obligatory to help, and vice versa, both parties must both feel helped and benefit. This is what researchers call the norm in the form of obligation. Obligations are 
something that must be and must be done. Mutual words are words that connect reciprocal relationships between groups. This becomes important to be able to achieve common goals. Individuals in groups will try to achieve a common goal only if the individual also benefits. Actions to achieve this common goal are needed norms or rules in running the work system.

When the responsibility for replacing labor with energy can sometimes not be fulfilled, farmers in the Remote Indigenous Community (RIC) make another agreement, namely calling for the front of wages. Therefore, if it is associated with social exchanges that occur in the said suit, not only are non-metrics exchanged, namely in the form of helping responsibilities, but also material things that are exchanged, namely wages.

Fourth is solidarity. Society basically always interacts, in sociology known as social interaction. Social interaction is dynamic social relationships that involve relationships between individuals, between human groups and between individuals and other groups. If two people meet, they rebuke each other, shake hands, talk to each other, or even fight, that's when social interaction begins.

With the solidarity they have strengthened the social capital that exists in the community of the Informed Communities (IC) in Durian Hamlet. They still tend to be homogeneous, aware of a unity, a sense of kinship, solidarity and strong trust among citizens. So it is clear that there is solidarity formed in the KAT community which is still mechanical. Mechanical solidarity is solidarity that arises from similarity (similarity), consensus and can be exchanged between individuals with other individuals in the group. There is no specificity in each individual. It was proven by the attitude of helping each other among the people, and they lent each other land to be cultivated.

\section{The Role of Local Wisdom as Social Capital;a prevention of conflict}

In local wisdom, of course local wisdom is contained. The wisdom of local culture is local knowledge that has become so integrated with the belief system, norms, and culture, and expressed in the traditions and myths that have been 
adhered to for a long time. The same thing happened in the community of Remote Indigenous Communities (RIC) which have their own wisdom available.

Huyula local wisdom has become the focus of this research because it is considered important to create social capital The value of local culture or wisdom such as "huyula" still seems to be a lord of the community, held and still aligned by the Remote Indigenous Community (RIC) with togetherness, cooperation and social relations which is good for producing a peaceful life. Tolerance and help in coexistence are the main sources of capital to interact.

In dealing with internal problems between communities, basically they do not need externalhelp to solve the problem, because the community is believed to have its own power to solve it together. This strengthissocial capital, where social capital emphasizes that there needs to be independence from the community to overcome its own social and political problems, external assistance is only a trigger for initiation and productivity in society. The independence of the community can also be seen from the explanation of the Village Head who explained that in fact the village government always provides a place to share and solve problems in the community, but the community can solve it themselves without any mediation from the village government for internal problems among them. It appears that the cultural values of the community groups have a balance between social capital that regulates the harmony and solidarity of internal relations among group members, which is called the term social capital bonding or social capital binding, with social capital that enables the creation of cooperation and mutually beneficial relationships with citizens from other ethnic groups, which are referred to as bridging social capital or bridge social capital.

\section{CONCLUSION}

This study found that the element of solidarity is important in building strong social capital in the community of Remote Indigenous Communities (RIC), this is different from Putnam who only emphasizes on three elements, namely 
trust, networks and norms. In addition, the researchers found that in the process of networking, the RIC community is not only dealing with people they know or people who are in their community, but also in the process of networking with other parties. They have good relations with the village government because they can help their business. In addition, they also conduct networking or collaborating with middlemen who are considered to be able to assist capital in their agriculture. This is different from that by Putnam that to realize various things, often people choose to skip the formal system and talk to people they know. Asking for help from friends, family or acquaintances who can be trusted is much easier than dealing with bureaucracy, and this seems to produce more satisfying results faster (Field, 2010, p. 3).

Huyula as one form of Gorontalo local wisdom which is a series of mutual cooperation and cooperation is still being carried out, but there are some who shift their value. The concept of Huyula (collaboration) for the life of the people of Gorontalo, it is more manifested in several forms. Like the First; Ambu, that is, help for common interests such as making new roads in the village and so on, which are more focused on community service. The huyula form in this ambu form is still well implemented in the Remote Indigenous Community (RIC) community in Durian Hamlet, they collaborated in cleaning up their living environment, building a gazebo, repairing living facilities and others as they wish. Researchers see this done because they feel they have shared responsibility for their relatively small neighborhood.

Second; Hileya; i.e. help spontaneously help for example if someone experiences a disaster such as a sad person, people who come to the place of sorrow besides entertaining, also bringing food and staying a few days. The huyula form in the form of hileya is still well implemented in the community of the Remote Indigenous Community (RRIC) of Durian Hamlet, they spontaneously and sincerely help families, relatives and neighbors who experience disaster. The researchers see it certainly inseparable from the system of kinship or ungalaa and solidarity that are still strong among them. 
Third; Tiayo; which is a helping activity between a group of people to do someone's work. The huyula form in the form of hileya is still applied to the people of the Remote Indigenous Community (RIC) of Durian Hamlet, but there are some who have slightly shifted its value. If previously this did not require material value (money), this then shift a little. Some people pay more attention to material values (money) in order to increase family income when compared with the way of cooperation through community members and other communities. In the KAT community, they still want to carry out the agricultural process both the nursery and harvesting process to be done jointly (tiayo) and provide material rewards or wages. From the field data, the researchers saw that farmers invited by other farmers did not want to pay back their exhaustion with energy but had been assessed with material, namely wages.

The huyula local wisdom that builds social capital in the community of Remote Indigenous Communities (RIC) is able to bridge the differences that exist in a community. The level of mechanism, social capital can take the form of cooperation, which in this case the RIC community often collaborates because they adhere to their local wisdom, namely "huyula" or mutual cooperation, as an effort to coordinate behavior which is of course needed to resolve conflicts. Strengthened by the elements of social capital such as trust, networks, norms and solidarity that make people able to solve their own problems. Especially in land tenure, the RIC community of Durian Hamlet only gets a system of mastery for generations, the land tenure system is still traditional, does not have certificates and the boundaries of land are only made by themselves. Therefore, the strength they have makes things that have the potential for conflict can be overcome on their own, of course with the trust between each other, networks or relationships that are built, compliance with agreements made, and certainly no less important is strong solidarity among the people of the Remote Indigenous Community (KAT) in Durian Hamlet, Buhu Village. 


\section{Reference}

Abdullah , S. 2013, Potensi dan Kekuatan Modal Sosial dalam Suatu Komunitas Volume XII. Socius , 1-8.

Adussammah, 1985, Empat Aspek Adat Gorontalo . Manado: FKIP Unsrat Manado .

Dinas Sosial Provinsi Grorontalo, 2014, Profil Komunitas Adat Terpencil di Wilayah Provinsi Gorontalo. Gorontalo.

Field, J, 2005, Medan: Bina Media Perintis.

Field, J, 2010, (Nurhadi, Penerj.) Bantul: Kreasi Wacana.

Hasbullah, J. ,2006, Social Capital (Manuju Keunggulan Budaya Manusia Indonesia). Jakarta: MR-United.

Hatu, R, 2005, Perubahan Budaya Huyula (Studi Kasus Pada Masyarakat Kecamatan Tibawa Kabupaten Gorontalo) VOL 2 NO 2. Jurnal Pengabdian Masyarakat, 126-151.

Lawang, R. M, 2004, Kapital Sosial Dalam Perspektif Sosiologi : Suatu Pengantar. Depok: FISIP UI PRESS.

Rifai'i, A, 2016, Konflik Kepemilikan Tanah di Masyarakat Kajujila Desa Sanalaok. Yogyakarta: Universitas Islam Negeri Sunan Kalijaga.

Suradi, 2013, Kebijakan Pemberdayaan Sosial Komunitas Adat Terpencil . Usman, S, 2018,Modal Sosial . Yogyakarta: Pustaka Pelajar. 